\title{
Trace Element Concentrations in Edible Wild Mushroom Samples From Turkey Determined by Atomic Absorption Methods Using Microwave Digestion vs. Wet Ashing
}

\author{
Durali Mendil*, Hilmi Bardak, and Mustafa Tüzen \\ Gaziosmanpasa University, Faculty of Science and Arts, Chemistry Department \\ 60250 Tokat, Turkey
}

\section{INTRODUCTION}

Mushrooms are a valuable, healthy food, low in calories and high in protein, vitamins, and minerals (1). Wild-growing mushrooms have been a popular delicacy in many countries, particularly in central and eastern Europe, and are a popular food source in Turkey (2-3). Mushroom picking is a "national hobby" in the Czech Republic, with a statistical mean of $5.6 \mathrm{~kg}$ per household per year. However, some individuals consume more than $10 \mathrm{~kg}$ per year (4-6). Mushrooms also have a long history of use in traditional Chinese medicine and are considered a therapeutic food in preventing diseases such as hypertension, hypercholesterolemia, and cancer. These functional characteristics are mainly due to the chemical composition of the mushrooms (2); thus, it is necessary to know the levels of their essential elements (7). Research regarding the trace element content of wild mushrooms has been ongoing since the 1970s (8).

Foods together with water provide the major portion of the total daily intake of trace elements. Knowledge about the trace element composition in foods is, therefore, important for both the consumer and the health professional. In recent years, food labeling legislation has highlighted this requirement (9). Heavy metal concentrations in mushrooms are consider-

\footnotetext{
* Corresponding autbor.

E-mail: durali.mendil@gop.edu.tr

Tel.: +903562521582

Fax: +903562521585
}

\begin{abstract}
In this study, the trace element concentrations of $\mathrm{Fe}, \mathrm{Cu}$, $\mathrm{Mn}$, and $\mathrm{Zn}$ in mushroom species were determined by flame atomic absorption spectrometry (FAAS) and $\mathrm{Cd}, \mathrm{Cr}, \mathrm{Ni}$, and $\mathrm{Pb}$ by graphite furnace (GFAAS) after wet ashing and microwave digestion. The results show that microwave digestion was best because it is simple, fast, and more accurate than wet ashing. The results were also compared to data reported in the literature. The mushrooms were collected in the middle region of Anatolia, Turkey, having metal concentrations of $21.4 \mu \mathrm{g} / \mathrm{g}(\mathrm{Cu}), 1.10 \mu \mathrm{g} / \mathrm{g}$ (Cd), $2.81 \mu \mathrm{g} / \mathrm{g}(\mathrm{Pb}), 74.5 \mu \mathrm{g} / \mathrm{g}$ ( $\mathrm{Zn}), 78.6 \mu \mathrm{g} / \mathrm{g}(\mathrm{Mn}), 389 \mu \mathrm{g} / \mathrm{g}$ (Fe), $1.30 \mu \mathrm{g} / \mathrm{g}(\mathrm{Cr})$, and 13.2 $\mu \mathrm{g} / \mathrm{g}(\mathrm{Ni})$. These levels are allowable limits, except for lead. The concentration of the trace elements in the samples is dependent on the type of mushroom species since some accumulate trace elements at higher levels. The $\mathrm{Pb}$ levels in the mushroom samples (some edible) from this region were found to be higher than the legal limit. The accuracy of the method was verified by using certified reference material.
\end{abstract}

ably higher than in agricultural crop plants, vegetables, and fruit (2) since many wild-growing species accumulate elements at high concentrations (10) due to environmental conditions. Compared to green plants, mushrooms can build up high concentrations of the heavy metals such as $\mathrm{Pb}$, $\mathrm{Cd}$, and $\mathrm{Hg}$. Therefore, great efforts have been made to evaluate their possible danger to human health (11). The heavy metal concentrations in mushrooms are mainly due to the acidic and organic matter content in the ecosystem and soil. The uptake of metal ions in mushrooms is in many respects different from plants. For this reason, the variation in metal concentrations depends on the mushroom species and their ecosystems (11-13).

Turkey has a large edible wild mushroom potential and is becoming an important exporter. The purpose of this study relates to the determination of toxic and essential elements (Cu, Cd, Pb, Zn, Mn, Fe, $\mathrm{Cr}$, and $\mathrm{Ni}$ ) in some mushroom species collected from the middle region of Anatolia, Turkey.

\section{EXPERIMENTAL}

\section{Instrumentation}

For this study, a PerkinElmer ${ }^{\circledR}$ AAnalyst ${ }^{\mathrm{TM}} 700$ flame atomic absorption spectrometer (FAAS), equipped with deuterium background corrector, was used for Fe, $\mathrm{Cu}, \mathrm{Mn}$, and $\mathrm{Zn}$ determination. The PerkinElmer ${ }^{\circledR}$ HGA ${ }^{\circledR} 700$ graphite furnace AAS was used for the determination of $\mathrm{Cd}, \mathrm{Cr}, \mathrm{Ni}$, and $\mathrm{Pb}$ (PerkinElmer Corporation, Shelton, CT, USA). An Elektro-mag m5040p oven (Elektro-mag A.S., Istanbul, Turkey) was used for drying the samples. The instrumental operating conditions are listed in Table I.

Microwave digestion was performed in an Ethos D microwave oven (Milestone, Italy). For wet ashing, a Model KS501D hot plate (IKA, Germany) was used. 


\section{Samples}

In this study, 20 mushroom samples of 18 different species were collected from the middle region of Anatolia (Sivas, Kayseri, Nevsehir, Nigde, and Yozgat). The samples were dried at $105^{\circ} \mathrm{C}$ for $24 \mathrm{~h}$ in the Elektro-mag oven. The dried samples were homogenized using an agate mill and then stored in polyethylene bottles until analysis.

\section{Reagents and Standard Solutions}

All reagents were of analytical reagent grade unless otherwise stated. Double deionized water was obtained with a Milli-Q ${ }^{\circledR}$ system, $\mathrm{M} \Omega-\mathrm{cm}$ resistivity (Millipore Corporation, USA) and was used for all dilutions. Suprapur ${ }^{\circledR} \mathrm{HNO}_{3}$ and $\mathrm{H}_{2} \mathrm{O}_{2}$ were obtained from E. Merck, Darmstadt, Germany. All plastic and glassware was cleaned by soaking overnight in a $10 \%(\mathrm{w} / \mathrm{v})$ nitric acid solution, then rinsed with deionized water. The standard solutions of the investigated elements (1000 $\mathrm{mg} / \mathrm{L}$ ) were prepared by dissolution of pure metals or their salts (E. Merck) and were further diluted prior to use. The matrix modifiers of $\mathrm{NH}_{4} \mathrm{H}_{2} \mathrm{PO}_{4}, \mathrm{Pd}$, and $\mathrm{Mg}\left(\mathrm{NO}_{3}\right)_{2}$ were purchased from Sigma Chemical Co., St. Louis, MO, USA. The standard reference material NIST SRM 1515 Apple Leaves (National Insitute of Standards and Technology, Bethesda, MD, USA) was used to establish the accuracy of the method.

\section{Analytical Procedure}

The elements $\mathrm{Pb}, \mathrm{Cr}, \mathrm{Ni}$, and $\mathrm{Cd}$ in the samples were determined using the PerkinElmer ${ }^{\circledR}$ HGA ${ }^{\circledR} 700$ graphite furnace AAS with argon as the inert gas. Pyrolytically coated graphite tubes with a platform were used for $\mathrm{Cr}, \mathrm{Ni}, \mathrm{Cd}$, and $\mathrm{Pb}$. The measurements for $\mathrm{Fe}, \mathrm{Cu}, \mathrm{Mn}$, and $\mathrm{Zn}$ were carried out in an air/acetylene flame. The operating parameters for the working

TABLE I

Instrumental Operating Conditions for FAAS and GFAAS

\begin{tabular}{|c|c|c|c|c|}
\hline \multicolumn{5}{|c|}{ FAAS - PerkinElmer ${ }^{\circledR}$ AAnalyst ${ }^{\mathrm{TM}} 700$ Flame AAS } \\
\hline Elemenst & $\begin{array}{l}\text { Acetylene } \\
\text { (L/min) }\end{array}$ & $\begin{array}{c}\text { Air } \\
(\mathrm{L} / \mathrm{min})\end{array}$ & $\begin{array}{l}\text { Wavelength } \\
\text { (nm) }\end{array}$ & $\begin{array}{l}\text { lit Width } \\
\text { (nm) }\end{array}$ \\
\hline $\mathrm{Fe}$ & 2.0 & 17.0 & 248.3 & 0.2 \\
\hline $\mathrm{Cu}$ & 2.0 & 17.0 & 324.8 & 0.7 \\
\hline Mn & 2.0 & 17.0 & 279.5 & 0.2 \\
\hline $\mathrm{Zn}$ & 2.0 & 17.0 & 213.9 & 0.7 \\
\hline \multicolumn{5}{|c|}{ GFAAS - PerkinElmer ${ }^{\circledR}$ HGA ${ }^{\circledR} 700$ Graphite Furnace AAS } \\
\hline Elements & $\mathrm{Pb}$ & Cd & $\mathrm{Ni}$ & $\mathrm{Cr}$ \\
\hline $\begin{array}{l}\text { Argon flow } \\
(\mathrm{mL} / \mathrm{min})\end{array}$ & 250 & 250 & 250 & 250 \\
\hline $\begin{array}{l}\text { Sample Volume } \\
(\mu \mathrm{L})\end{array}$ & 20 & 20 & 20 & 20 \\
\hline Modifier $(\mu \mathrm{L})$ & 5 & 10 & 5 & 5 \\
\hline \multicolumn{5}{|c|}{ Heating Program Temperature ${ }^{\circ} \mathrm{C}$, ramp time (s), hold time (s) } \\
\hline Drying 1 & $100(5,20)$ & $100(5,20)$ & $100(5,20)$ & $100(5,20)$ \\
\hline Drying 2 & $140(15,15)$ & $140(15,15)$ & $140(15,15)$ & $140(15,15)$ \\
\hline Ashing & $700(10,20)$ & $850(10,20)$ & $1300(10,20)$ & $1600(10,20)$ \\
\hline Atomization & $1800(0,5)$ & $1650(0,5)$ & $2500(0,5)$ & $2500(0,5)$ \\
\hline Cleaning & $2600(1,3)$ & $2600(1,3)$ & $2600(1,3)$ & $2600(1,3)$ \\
\hline
\end{tabular}

\section{Atomic Apectroscopy \\ 1 Vol. 36(6), Nov./Dec. 2015}

elements were set as recommended by the manufacturer (Table I). All metal concentrations were determined on a dry weight basis.

The detection limit is defined as the concentration corresponding to three times the standard deviation of 10 blanks. The detection limits otained by flame AAS were 0.10 $\mu \mathrm{g} / \mathrm{g}$ for $\mathrm{Cu}, 0.15 \mu \mathrm{g} / \mathrm{g}$ for $\mathrm{Zn}, 0.20$ $\mu \mathrm{g} / \mathrm{g}$ for $\mathrm{Mn}, 0.25 \mu \mathrm{g} / \mathrm{g}$ for Fe. The detection limits for $\mathrm{Pb}, \mathrm{Cd}, \mathrm{Cr}$, and $\mathrm{Ni}$ were below flame AAS detection and thus were determined by GFAAS. The values obtained were $0.01 \mu \mathrm{g} / \mathrm{kg}$ for $\mathrm{Cd}, 0.02 \mu \mathrm{g} / \mathrm{kg}$ for $\mathrm{Pb}, 0.03$ $\mu \mathrm{g} / \mathrm{kg}$ for $\mathrm{Cr}$, and $0.04 \mu \mathrm{g} / \mathrm{kg}$ for $\mathrm{Ni}$. The amount of matrix modifier added for $\mathrm{Pb}$ determination was $200 \mu \mathrm{g} \mathrm{NH} \mathrm{NH}_{2} \mathrm{PO}_{4}$, and for $\mathrm{Cd}, \mathrm{Cr}$, and for $\mathrm{Ni}$ it was $15 \mu \mathrm{g} \mathrm{Pd}+10 \mu \mathrm{g}$ $\mathrm{Mg}\left(\mathrm{NO}_{3}\right)_{2}$.

\section{Microwave Digestion Procedures}

For digestion, a Milestone Ethos D microwave closed system (maximum pressure $1450 \mathrm{psi}$, maximum temperature $300{ }^{\circ} \mathrm{C}$ ) (Milestone, Italy) was used. Samples of $0.5 \mathrm{~g}$ were digested with $6 \mathrm{~mL}$ of $\mathrm{HNO}_{3}$ (65\%) and $1 \mathrm{~mL}$ of $\mathrm{H}_{2} \mathrm{O}_{2}(30 \%)$ in the microwave digestion system for 23 minutes, then diluted to $10-\mathrm{mL}$ volume with deionized water. A blank digest was carried out in the same way. The digestion conditions for the microwave system were as follows: 2 minutes for $250 \mathrm{~W}$, 2 minutes for $0 \mathrm{~W}, 6$ minutes for $250 \mathrm{~W}, 5$ minutes for the $400 \mathrm{~W}$, 8 minutes for $550 \mathrm{~W}$, and venting for 8 minutes.

\section{Wet Ashing}

A 0.5-g sample was digested with a mixture of $\mathrm{HNO}_{3} / \mathrm{H}_{2} \mathrm{O}_{2}(6: 2)$ on a hot plate (Model KS501D) for solubilization at $130{ }^{\circ} \mathrm{C}$ for 4 hours. This procedure was repeated two times. The residue was filtered through a Whatman filter paper (Whatman grade 589) and brought to $10-\mathrm{mL}$ volume with distilled deionized water. The element con- 
centrations of the sample solution were determined by AAS. Blanks were prepared in the same way but without the samples.

\section{Statistical Analysis}

All of the data was subjected to a statistical analysis and correlation matrices were produced to examine the inter-relationships between the investigated trace element concentrations of the samples. A Student's $t$-test was employed to estimate the significance of the values.

\section{RESULTS AND DISCUSSION}

The recovery values were found to be nearly quantitative ( $\geq 95 \%$ ) for the microwave digestion and wet ashing methods. The relative standard deviations were less than $10 \%$ for all of the investigated elements. The Student's $t$-test was used in this study $(\mathrm{p}<0.05)$. The accuracy of the method was evaluated by means of trace element determination in standard reference material NISTSRM 1515 Apple Leaves (National Institute of Standards and Technology, Gaithersburg, MD, USA). The achieved results were found to be in good agreement with the certified values, and the results are listed in Table II.

A comparison of the results of the wet and microwave digestion methods forthe standard reference material NIST SRM 1515 Apple Leaves shows that there are no statistical differences (Table II). Thus, we selected the microwave digestion method because it is simple, fast, and more accurate for the determination of trace elements by AAS.

In this study, 20 mushroom samples were analyzed for eight elements. The habitat and genetic families of the edible mushroom samples are listed in Table III. The trace element concentrations (mean \pm standard deviation) in the mushroom species are listed Table IV.
The trace element levels for $\mathrm{Cu}$, $\mathrm{Cd}, \mathrm{Pb}, \mathrm{Zn}, \mathrm{Mn}, \mathrm{Fe}, \mathrm{Cr}$, and Ni were 4.42-21.4, 0.11-1.10, 0.26-2.81, 14.5-74.5, 11.1-78.6, 101-389, $0.20-1.30$, and $2.89-13.2 \mu \mathrm{g} / \mathrm{g}$, respectively (see Figures 1-8).

\section{TABLE II}

Analysis of NIST SRM 1515 Apple Leaves After Microwave and Wet Digestion Methods ( $\mu \mathrm{g} / \mathrm{g}$, Average \pm S.D.)

\begin{tabular}{cclccc}
\hline Element & $\begin{array}{c}\text { Certified } \\
\text { Value }\end{array}$ & $\begin{array}{l}\text { Microwave } \\
\text { Digestion }^{\mathrm{a}}\end{array}$ & $\begin{array}{c}\text { Recovery } \\
(\%)\end{array}$ & $\begin{array}{c}\text { Wet- } \\
\text { Ashing }^{\mathrm{a}}\end{array}$ & $\begin{array}{c}\text { Recovery } \\
(\%)\end{array}$ \\
\hline $\mathrm{Cu}$ & 5.64 & $5.57 \pm 0.30$ & 99 & $5.48 \pm 0.40$ & 95 \\
$\mathrm{Cd}$ & 0.013 & $0.013 \pm 0.001$ & 100 & $0.012 \pm 0.001$ & 96 \\
$\mathrm{~Pb}$ & 0.47 & $0.46 \pm 0.04$ & 98 & $0.45 \pm 0.05$ & 95 \\
$\mathrm{Zn}$ & 12.5 & $12.4 \pm 0.5$ & 99 & $11.9 \pm 0.9$ & 96 \\
$\mathrm{Mn}$ & 54 & $52.4 \pm 3.7$ & 97 & $51.6 \pm 5.2$ & 95 \\
$\mathrm{Fe}$ & 83 & $82.1 \pm 5.2$ & 99 & $81.3 \pm 7.7$ & 95 \\
$\mathrm{Cr}$ & $(0.3)^{\mathrm{b}}$ & $0.29 \pm 0.02$ & 97 & $0.27 \pm 0.03$ & 95 \\
$\mathrm{Ni}$ & 0.91 & $0.88 \pm 0.05$ & 97 & $0.86 \pm 0.08$ & 95 \\
\hline
\end{tabular}

${ }^{\text {a }}$ Data presented as mean \pm standard deviation.

$\mathrm{b}$ The value in parenthesis is not certified.

Table III Habitat of Edible Mushroom Species

Edible Mushroom Species
Suillus luteus (L.) Roussel
Coprinus atramentarius (Bull.) Fr.

Agaricus bitorquis (Quél.) Sacc. Pleurotus ostreatus (Jacq.) P. Kumm.

Stropharia coronilla (Bull.) Quél. Agrocybe dura (Bolton) Singer Marasmius oreades (Bolton) Fr. Tricholoma argyraceum (Bull.) Gillet Agaricus bisporus (J.E. Lange) Imbach

Hygrocybe nigrescens (Quél.) Kühner Stropharia coronilla (Bull.) Quél. Coprinus comatus (O.F. Müll.) Pers.

Lactarius piperatus (L.) Pers. Pleurotus ostreatus (Jacq.) P. Kumm. Agaricus campestris Schwein. Habitat Conifers, usually pine Near rotting or buried wood, or in grass In gardens and at roadsides On stumps, usually of deciduous trees

Lawns and pasture

At roadsides or in meadows In pasture or lawns Singly or in groups in mixed woods Manure heaps, garden waste, and roadsides

Among grass in fields or woods On lawns and in pasture

On roadsides, lawns, and other urban sites

Deciduous woods

Deciduous trees, especially beech In pasture

Deciduous woods

In woodland, hedgerows, gardens Conifers, usually pines 


\section{Atomic Apectroscopy \\ Vol. 36(6), Nov./Dec. 2015}

TABLE IV

Trace Elements Concentrations $(\mu \mathrm{g} / \mathrm{g})$ in Mushroom Species (mean \pm standard deviation)

\begin{tabular}{|c|c|c|c|c|c|c|c|c|c|}
\hline $\begin{array}{l}\text { Sample } \\
\text { Location }\end{array}$ & Mushroom Species & $\mathrm{Cu}$ & $\mathrm{Cd}$ & $\mathrm{Pb}$ & $\mathrm{Zn}$ & Mn & $\mathrm{Fe}$ & $\mathrm{Cr}$ & $\mathrm{Ni}$ \\
\hline \multirow[t]{4}{*}{ Sivas } & Suillus luteus & $11.5 \pm 1.8$ & $0.32 \pm 0.03$ & $0.26 \pm 0.02$ & $36.7 \pm 3.4$ & $12.2 \pm 1.1$ & $161 \pm 14$ & $0.32 \pm 0.03$ & $3.91 \pm 0.34$ \\
\hline & Coprinus atramentarus & $10.7 \pm 1.0$ & $0.21 \pm 0.02$ & $0.36 \pm 0.03$ & $65.3 \pm 6.2$ & $21.3 \pm 2.0$ & $193 \pm 18$ & $0.32 \pm 0.03$ & $4.60 \pm 0.43$ \\
\hline & Agaricus bitorquis & $17.2 \pm 1.4$ & $0.18 \pm 0.02$ & $0.67 \pm 0.07$ & $46.0 \pm 3.9$ & $35.5 \pm 3.2$ & $176 \pm 18$ & $0.85 \pm 0.07$ & $3.17 \pm 0.30$ \\
\hline & Plevnotus ostreatus & $4.42 \pm 0.38$ & $0.27 \pm 0.02$ & $0.52 \pm 0.05$ & $53.7 \pm 5.1$ & $20.0 \pm 1.8$ & $101 \pm 10$ & $0.49 \pm 0.05$ & $3.82 \pm 0.37$ \\
\hline \multirow[t]{4}{*}{ Kayseri } & Stropharia coronilla & $13.7 \pm 1.3$ & $0.22 \pm 0.02$ & $0.75 \pm 0.08$ & $74.5 \pm 6.2$ & $20.0 \pm 1.7$ & $180 \pm 17$ & $0.78 \pm 0.07$ & $9.21 \pm 0.89$ \\
\hline & Agrocybe dura & $15.4 \pm 1.4$ & $0.44 \pm 0.04$ & $1.20 \pm 0.11$ & $33.9 \pm 3.1$ & $18.6 \pm 1.6$ & $132 \pm 10$ & $0.32 \pm 0.03$ & $5.20 \pm 0.48$ \\
\hline & Marasmius oreades & $33.9 \pm 3.3$ & $0.62 \pm 0.06$ & $1.10 \pm 0.10$ & $53.4 \pm 5.2$ & $25.1 \pm 2.3$ & $221 \pm 19$ & $1.11 \pm 0.11$ & $13.2 \pm 1.2$ \\
\hline & Tricholoma argyraceum & $12.3 \pm 1.2$ & $0.80 \pm 0.08$ & $1.90 \pm 0.11$ & $69.5 \pm 6.0$ & $15.5 \pm 1.4$ & $107 \pm 10$ & $0.42 \pm 0.04$ & $5.75 \pm 0.49$ \\
\hline \multirow[t]{5}{*}{ Nevsehir } & Agaricus bisporus & $7.58 \pm 0.62$ & $0.17 \pm 0.01$ & $0.36 \pm 0.03$ & $37.7 \pm 3.4$ & $17.7 \pm 1.8$ & $162 \pm 15$ & $0.32 \pm 0.03$ & $8.60 \pm 0.83$ \\
\hline & Hygrocybe nigrescens & $10.2 \pm 1.0$ & $0.19 \pm 0.02$ & $0.28 \pm 0.02$ & $43.2 \pm 4.0$ & $13.2 \pm 1.2$ & $129 \pm 12$ & $0.49 \pm 0.05$ & $4.63 \pm 0.42$ \\
\hline & Stroporia coronilla & $7.13 \pm 0.70$ & $0.18 \pm 0.01$ & $0.52 \pm 0.05$ & $20.6 \pm 1.9$ & $22.3 \pm 2.0$ & $295 \pm 26$ & $1.08 \pm 0.10$ & $6.81 \pm 0.67$ \\
\hline & Inocybe fastigiata & $5.46 \pm 0.48$ & $0.23 \pm 0.02$ & $0.23 \pm 0.02$ & $27.7 \pm 2.8$ & $16.3 \pm 1.6$ & $166 \pm 12$ & $0.38 \pm 0.04$ & $3.95 \pm 0.38$ \\
\hline & Lepiota cristata & $10.2 \pm 1.0$ & $0.12 \pm 0.01$ & $0.52 \pm 0.05$ & $17.8 \pm 1.6$ & $15.4 \pm 1.3$ & $101 \pm 10$ & $0.38 \pm 0.04$ & $5.60 \pm 0.54$ \\
\hline \multirow[t]{4}{*}{ Nigde } & Coprinus comatus & $20.4 \pm 1.9$ & $1.10 \pm 0.10$ & $2.81 \pm 0.24$ & $16.4 \pm 1.4$ & $29.4 \pm 2.5$ & $336 \pm 29$ & $0.23 \pm 0.02$ & $4.73 \pm 0.43$ \\
\hline & Lactarius piperatus & $16.3 \pm 1.5$ & $0.48 \pm 0.05$ & $1.30 \pm 0.12$ & $46.1 \pm 3.9$ & $78.6 \pm 7.2$ & $389 \pm 35$ & $1.30 \pm 0.12$ & $6.11 \pm 0.59$ \\
\hline & Pleurotus ostreatus & $13.1 \pm 1.3$ & $0.52 \pm 0.04$ & $2.31 \pm 0.20$ & $73.5 \pm 6.9$ & $23.2 \pm 1.9$ & $267 \pm 24$ & $0.34 \pm 0.03$ & $2.89 \pm 0.27$ \\
\hline & Agaricus campestris & $15.9 \pm 1.5$ & $0.63 \pm 0.05$ & $1.40 \pm 0.14$ & $48.3 \pm 4.5$ & $11.1 \pm 1.1$ & $360 \pm 29$ & $1.11 \pm 0.10$ & $4.83 \pm 0.44$ \\
\hline \multirow[t]{6}{*}{ Yozgat } & Agaricus campestris & $9.11 \pm 0.87$ & $0.85 \pm 0.07$ & $0.28 \pm 0.03$ & $32.2 \pm 2.9$ & $22.4 \pm 2.1$ & $284 \pm 26$ & $0.92 \pm 0.08$ & $3.96 \pm 0.34$ \\
\hline & Lactarius piperatus & $6.82 \pm 0.64$ & $0.54 \pm 0.05$ & $0.52 \pm 0.05$ & $68.6 \pm 6.6$ & $21.1 \pm 2.1$ & $102 \pm 10$ & $0.26 \pm 0.02$ & $3.63 \pm 0.35$ \\
\hline & Agaricus bisporus & $17.1 \pm 1.5$ & $0.37 \pm 0.04$ & $1.90 \pm 0.18$ & $72.3 \pm 6.9$ & $43.5 \pm 3.9$ & $168 \pm 15$ & $0.32 \pm 0.03$ & $4.60 \pm 0.41$ \\
\hline & Lepista nuda & $21.4 \pm 3.1$ & $0.18 \pm 0.02$ & $0.52 \pm 0.04$ & $61.4 \pm 6.0$ & $16.8 \pm 1.3$ & $154 \pm 15$ & $0.21 \pm 0.02$ & $3.88 \pm 0.38$ \\
\hline & Chrogompus rutilus & $6.20 \pm 0.59$ & $0.11 \pm 0.01$ & $0.62 \pm 0.06$ & $14.5 \pm 1.4$ & $13.4 \pm 1.2$ & $134 \pm 13$ & $0.20 \pm 0.03$ & $4.91 \pm 0.48$ \\
\hline & Fomes fomentarius & $8.23 \pm 0.79$ & $0.23 \pm 0.02$ & $0.67 \pm 0.06$ & $34.2 \pm 3.4$ & $17.0 \pm 1.6$ & $162 \pm 15$ & $0.20 \pm 0.02$ & $5.64 \pm 0.43$ \\
\hline
\end{tabular}

TABLE V

Correlation Between Metal Concentrations

\begin{tabular}{lllllllll}
\hline & $\mathrm{Cu}$ & $\mathrm{Cd}$ & $\mathrm{Pb}$ & $\mathrm{Zn}$ & $\mathrm{Mn}$ & $\mathrm{Fe}$ & $\mathrm{Cr}$ & $\mathrm{Ni}$ \\
\hline $\mathrm{Cu}$ & 1.000 & & & & & & & \\
$\mathrm{Cd}$ & 0.328 & 1.000 & & & & & & \\
$\mathrm{~Pb}$ & 0.410 & 0.649 & 1.000 & & & & & \\
$\mathrm{Zn}$ & 0.149 & -0.064 & 0.127 & 1.000 & & & & \\
$\mathrm{Mn}$ & 0.254 & 0.114 & 0.287 & 0.073 & 1.000 & & & \\
$\mathrm{Fe}$ & 0.287 & 0.440 & 0.389 & -0.278 & 0.048 & 1.000 & & \\
$\mathrm{Cr}$ & 0.275 & 0.114 & -0.081 & -0.087 & 0.427 & 0.630 & 1.000 & \\
$\mathrm{Ni}$ & 0.471 & -0.003 & -0.040 & 0.003 & 0.043 & 0.090 & 0.417 & 1.000 \\
\hline
\end{tabular}

ostreatus. The $\mathrm{Cu}$ concentrations of mushroom samples reported in the literature are in the range of $4.71-51.0 \mu \mathrm{g} / \mathrm{g}(14), 12-181 \mu \mathrm{g} / \mathrm{g}$ (15), and 10.3-145 $\mu \mathrm{g} / \mathrm{g}(16)$, respectively. These $\mathrm{Cu}$ values are higher than our values. The FAO/ WHO provisional tolerable daily intake (PTDI) limits for heavy metal intake based on an average adult body weight of $60 \mathrm{~kg}$ are $214 \mu \mathrm{g}$ for $\mathrm{Pb}, 48 \mathrm{mg}$ for $\mathrm{Fe}, 3 \mathrm{mg}$ for $\mathrm{Cu}$, and $60 \mathrm{mg}$ for $\mathrm{Zn}(17)$. The $\mathrm{Cu}$ levels in the analyzed samples were found to be in agreement with the FAO/WHO tolerable levels. 

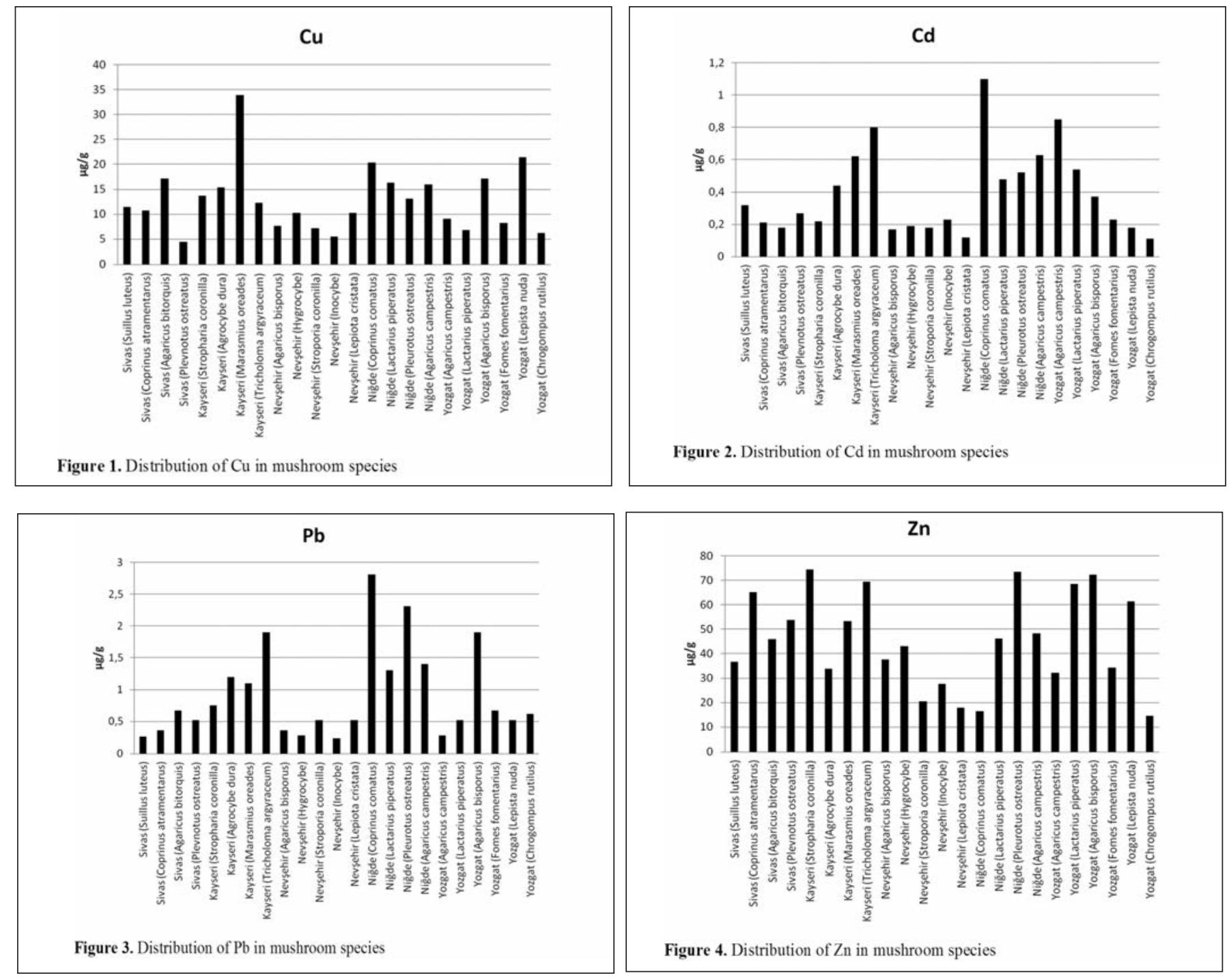

Figure 4. Distribution of $\mathrm{Zn}$ in mushroom species
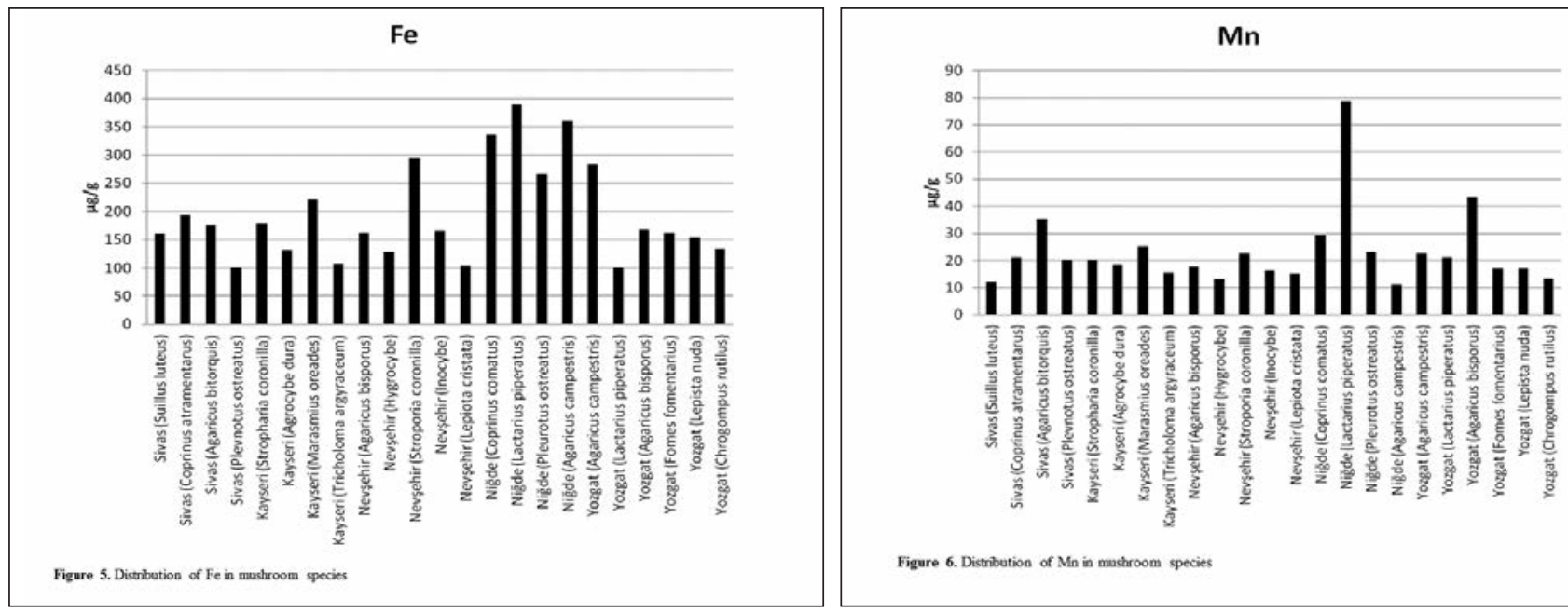

Figure 6. Distribution of $\mathrm{Mn}$ in mustroom species 

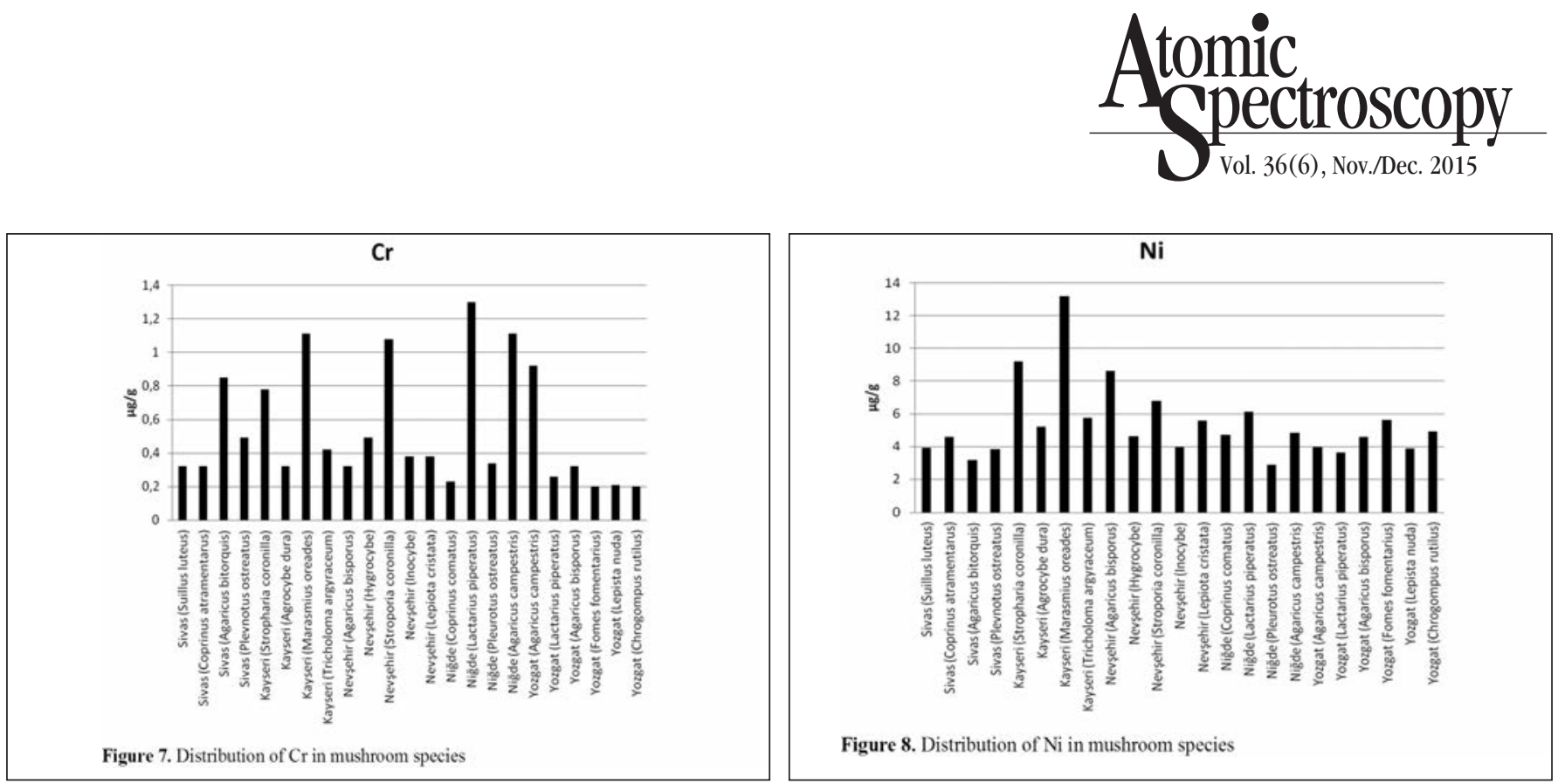

\section{Cadmium (Cd) and Lead (Pb)}

The mean Cd levels of the mushroom samples varied from 0.11 to $1.10 \mu \mathrm{g} / \mathrm{g}$. The $\mathrm{Pb}$ concentrations were generally low, and the highest concentration was $2.81 \mu \mathrm{g} / \mathrm{g}$ in Coprinus comatus. The reported $\mathrm{Pb}$ values for mushrooms were $0.5-20 \mathrm{mg} \mathrm{kg}^{-1}(16,18)$ and for $\mathrm{Cd}$ were between $2.71-7.5 \mathrm{mg} \mathrm{kg}^{-1}$ (7, 19, 16) (Figures 2-3). It can be seen that toxic metals can be present in high concentrations in mushrooms. According to FAO/WHO (1976) standards, the maximum permissible intake for an adult per week is $3 \mathrm{mg} \mathrm{Pb}$ and $0.5 \mathrm{mg} \mathrm{Cd}$, while the recommended doses are only onefifth of those quantities (20). The $\mathrm{Cd}$ and $\mathrm{Pb}$ levels found in the analyzed samples of this study are in agreement with the FAO/WHO tolerable levels.

\section{Zinc (Zn)}

Zinc is one of the most important trace metals necessary for normal growth and development of humans and animals. A deficiency in $\mathrm{Zn}$ can result from inadequate dietary intake, impaired absorption, excessive excretion or inherited defects in the $\mathrm{Zn}$ metabolism. Mushrooms are known as $\mathrm{Zn}$ accumulators and sporophores. The substrate ratio for $\mathrm{Zn}$ ranges from 1 to $10 \mathrm{mg} \mathrm{kg}^{-1}(7,21)$. In this study, the highest $\mathrm{Zn}$ level observed was $74.5 \mu \mathrm{g} / \mathrm{g}$ in Stropharia coronilla and ranged from 14.5 to $73.5 \mu \mathrm{g} / \mathrm{g}$ in others (Figure 4). Reported $\mathrm{Zn}$ concentrations in mushrooms range from $9.9-118 \mu \mathrm{g} / \mathrm{g}(22)$, 30-150 mg kg-1 (8), 21-100 mg $\mathrm{kg}^{-1}$ (23), to $35-136 \mathrm{mg} \mathrm{kg}^{-1}$ (24). The $\mathrm{Zn}$ levels in the analyzed samples of this study are in agreement with the FAO/WHO tolerable levels.

\section{Iron (Fe), Manganese (Mn), Chromium (Cr)}

The Fe levels in the mushroom samples studied were higher than the other metals. The highest concentrations of $\mathrm{Mn}, \mathrm{Fe}$, and $\mathrm{Cr}$ were $78.6 \mu \mathrm{g} / \mathrm{g}, 389 \mu \mathrm{g} / \mathrm{g}$, and $1.30 \mu \mathrm{g} / \mathrm{g}$ in Lactarius piperatus, respectively (Figures 5-7). The lowest levels were for Mn at $11.1 \mu \mathrm{g} / \mathrm{g}$ in Agaricus cam-pestris, Fe at $101 \mu \mathrm{g} / \mathrm{g}$ in Plevnotus ostreatus, and $\mathrm{Cr}$ at 0.20 $\mu \mathrm{g} / \mathrm{g}$ in Chrogompus rutilu. The Fe concentrations in mushroom samples have been reported in the range of 31.3-1190 $\mathrm{mg} \mathrm{kg}^{-1}$ (25), $50-842 \mathrm{mg} \mathrm{kg}^{-1}$ (3), and 38.9-499.0 $\mathrm{mg} \mathrm{kg}^{-1}(26)$. The observed Fe values obtained in this study are lower than these reported data. For Fe, the concentrations were reported as 5.3-252 mg kg-1 and for Mn between $5.42-41.3 \mathrm{mg} \mathrm{kg}^{-1}$ (22). The $\mathrm{Fe}, \mathrm{Mn}$, and Cr levels in the analyzed samples of this study are in agreement with the $\mathrm{FAO} / \mathrm{WHO}$ tolerable levels.

\section{Nickel (Ni)}

The highest and lowest Ni levels were $13.2 \mu \mathrm{g} / \mathrm{g}$ in Marasmius oreades and $2.89 \mu \mathrm{g} / \mathrm{g}$ in Pleurotus ostreatus, respectively (Figure 8). Nickel values are reported as $1.18-5.14 \mu \mathrm{g} / \mathrm{g}(19)$ and 8.2-21.6 $\mu \mathrm{g} / \mathrm{g}(28)$. Our nickel values are higher than the values obtained by Mendil et al. in 2004 (10) (4.2-8.2 $\mathrm{mg} / \mathrm{kg}$ ) and lower than the Mendil et al. values obtained in 2005 (28) $(21.6 \mathrm{mg} / \mathrm{kg})$. According to the Turkish Food Codex (29), the maximum $\mathrm{Pb}$ level permitted for wild edible mushrooms is $1 \mathrm{mg} / \mathrm{kg}$. The Codex does not list any information about maximum permitted levels of other elements for wild edible mushrooms. The Ni levels in the analyzed samples are in agreement with the FAO/WHO tolerable levels.

\section{Correlation Coefficients}

The values of the correlation coefficients between the metal concentrations are listed in Table V. There is good correlation between cadmium-lead $(r=0.649)$ and ironchromium ( $r=0.630)$. There is positive correlation between coppercadmium, copper-lead, copper-zinc, copper-manganese, copper-iron, 
copper-chromium, cadmium-manganese, cadmium-iron, cadmiumchromium, lead-zinc, lead-manganese, lead-iron, zinc-manganese, zinc-nickel, manganese-iron, manganese-chromium, manganesenickel, iron-chromium, iron-nickel and chromium-nickel. Negative correlations between copper-nickel, cadmium-zinc, cadmium-nickel, lead-chromium, lead-nickel, zinciron, and zinc-chromium were found as $0.471,0.064,0.003,0.081$, $0.040,0.278$ and 0.087 , respectively.

\section{CONCLUSION}

Microwave digestion of samples in comparison to wet ashing was found to be more simple, fast, and accurate. The study showed that the concentration of trace elements in the samples is dependent on the type of mushroom species. Some species accumulate trace elements at high levels. The metal concentrations in the mushrooms collected in the middle region of Anatolia, Turkey, were determined by FAAS and the values found were: $\mathrm{Cu}$ at $21.4 \mu \mathrm{g} / \mathrm{g}$, Fe at $389 \mu \mathrm{g} / \mathrm{g}, \mathrm{Mn}$ at $78.6 \mu \mathrm{g} / \mathrm{g}, \mathrm{Zn}$ at $74.5 \mu \mathrm{g} / \mathrm{g}$, and by GFAAS for Cd at $1.10 \mu \mathrm{g} / \mathrm{g}, \mathrm{Cr}$ at $1.30 \mu \mathrm{g} / \mathrm{g}, \mathrm{Ni}$ at $13.2 \mu \mathrm{g} / \mathrm{g}$, and $\mathrm{Pb}$ at $2.81 \mu \mathrm{g} / \mathrm{g}$. These levels, except for $\mathrm{Pb}$, are within the allowable limits. The lead levels in some edible mushroom samples were found to be higher than the legal limits. For public health reasons, wild edible mushrooms should, therefore, be sampled and analyzed more frequently to establish their toxic metal concentration status. The accuracy of the method was verified by using certified reference material and quantitative recovery values were obtained.

\section{ACKNOWLEDGMENT}

The authors wish to thank Dr. Ibrahim Türkekul for identification of the mushroom species. The authors are grateful for the financial support of the Unit of the Scientific
Research Projects of Gaziosmanpasa University, Tokat, Turkey.

Received January 27, 2015.

\section{REFERENCES}

1. L. Racz, L. Papp, B. Prokai, and Z. Kovacz, Microchem. J. 54, 444 (1996)

2. P. Manzi, A. Aguzzi, and L. Pizzoferrato, Food Chem. 73, 321 (2001).

3. H. Genccelep, Y. Uzun, Y. Tunctürk, and K. Demirel, Food Chem. 113, 1033 (2009).

4. L. Sisak, Mykologicky Sborník 84, 78 (2007) [in Czech].

5. M. De Roman, E. Boa, and S. Woodward, Wild-gathered fungi for health and rural livelihoods, Proceedings of the Nutritional Society 65, 190 (2006).

6. P. Kalac, Food Chem. 122, 2 (2010).

7. M. Isıloglu, F. Yilmaz, and M. Merdivan, Food Chem. 73, 163 (2001).

8 P. Kalac and L. Svoboda, Food Chem. 69, 273 (2000).

9. M.N. Matos-Reyes, M.L. Cervera, R.C. Campos, and M. de la Guardia, Food Chem.122, 188 (2010).

10. D. Mendil, O.D. Uluözlu, E. Hasdemir, and A. Caglar, Food Chem. 88, 281 (2004).

11. C.H. Gast, E. Jansen, J. Bierling, and L. Haanstra, Chemosphere 17, 789 (1988)

12. R. Seeger, Deutsche Apotheke Zeitschrift 122, 1835 (1982).

13. C. Sarikurkcu, M. Copur, D. Yildiz, and I. Akata, Food Chem. 128, 731 (2011).

14. M. Tüzen, M. Ozdemir, and A. Demirbaş, Food Chem. 63, 247 (1998).

15. M.Tüzen, I. Turkekul, E. Hasdemir, D. Mendil, and H. Sarı, Anal. Lett. 36, 1401 (2003).

16. E. Sesli, and M. Tüzen, Food Chem. 65, 453 (1999).

17. Joint FAO/WHO, Expert committee on food additives. Summary and conclusions 53rd meeting, Rome, Italy (1-10 June, 1999).

18. P. Kalac, M. Wittingerova, and I. Staskova, Potravinarske Vedy 7 , 131 (1989) [in Czech].

19. M. Tüzen, Microchem. J. 74, 289 (2003).

20. FAO/WHO, Standards, List of maximum levels recommended for contaminants by the Joint FAO/WHO Codex Alimentarius Commission Second Series CAC/FAL, Rome, Italy, Vol. 3, pp.1-8 (1976).

21. Z. Bano, K. Nagaraja, S. Vibhakar, and O.P. Kapur, Newsletter Tropics 2, 3 (1981).

22. Ö.F. Yeşil, A. Yildiz, and Ö. Yavuz, Bull. Environ. Contam. Toxicol. 73, 853 (2004).

23. A. Cayır, M. Coskun, and M. Coskun, Biol. Trace Elem Res. 134, 212 (2010).

24. C. Radulescu, C. Stihi, G. Busuioc, A.I. Gheboianu, and I.V. Popescu, Bull. Environ. Contam. Toxicol. 84, 641 (2010).

25. M.R. Kojo, and M. Lodenius, Angewandte Botanik 63, 279 (1989).

26. P.K. Ouzouni, D. Petridis, W.D. Koller, A. Kyriakos, and K.A. Riganakos, Food Chem. 115, 1575 (2009).

27. F.N. Marzano, P.G. Bracchi, and P. Pizzetti, Environmental Research Section A 85, 260 (2001).

28. D. Mendil, Ö.D. Uluözlü, M. Tüzen, E. Hasdemir, and H. Sar1, Food Chem. 91, 463 (2005).

29. Anonymous, Regulation of setting maximum levels for certain contaminants in foodstuffs. Official Gazette, October 16, 2002, Iss: 24908. 